\title{
Investigation of the population area of snow leopard in the Central Tian-Shan Mountains
}

\author{
Mirlan Dyldaev ${ }^{1}$, Akylbek Chymyrov ${ }^{2, *}$, Askat Mukabaev ${ }^{3}$ and Orozbek Omurzak uulu ${ }^{1}$ \\ ${ }^{1}$ Bishkek State University named after K. Karasaev, 27, Aitmatov street, Bishkek, 720044, \\ Kyrgyzstan \\ ${ }^{2}$ Kyrgyz State University of Construction, Transport and Architecture, 34 "b", Maldybaev street, \\ Bishkek, 720020, Kyrgyzstan \\ ${ }^{3}$ Institute of Geology, National Academy of Sciences, 30, Erkindik Ave., Bishkek, 720461, \\ Kyrghyzstan
}

\begin{abstract}
The spatial analysis of population areal of snow leopards in the Central Tian Shan Mountains and monitoring of their population dynamics and reproduction is needed by nature conservation activities. The study area is located in the unique and remote transboundary region between the Kyrgyz Republic, Republic of Kazakhstan and People's Republic of China. The population areas, feeding base and movement of snow leopards within the Khan Tengri State Nature Park were realized by using camera traps and Geoinformation Systems (GIS). Camera traps have been used for recording the existence and activity of snow leopards in the high mountainous and uninhabited area. 14 adult and 5 snow leopard cubs are detected and recorded within the survey period in 2018-2019 with various individual characteristics of animals. The spatial distribution of snow leopard's population was mapped and analyzed by applying open source GIS software (Quantum GIS) and satellite positioning.
\end{abstract}

Keywords: snow leopard, GIS, GPS, camera trap, monitoring

\section{Introduction}

Investigation and analysis of the distribution range (areal) of the snow leopard (Uncia uncia) and other endangered species of large mammals are currently of great scientific interest, which is growing because of the climate change issues. The number of snow leopard declined from an estimated 600-700 individuals in the late 1980s [1] to 150-200 individuals by 2000 [2] has putting the species at high risk of extinction in the Kyrgyz Republic. Its main prey species - mountain goats (Capra sibirica) and argali (Ovis ammon) are also threatened by illegal or unsustainable hunting in many parts of the snow leopard range. Climate change impact is increasingly affecting the snow leopard population because of the glacier loss resulting in the reduced feeding area of its main prey and disturbance caused by increasing altitude of highland pasture grazing [3,4].

The National Academy of Sciences of the Kyrgyz Republic has declared that number of snow leopards has been slowly improving because of the environmental protection

* Corresponding author: chymyrov@gmail.com 
activities and national legislation has been strengthened (250-300 in 2010 and 330 in 2019) [5]. But these numbers are resulted from the traditional research methodology based mainly on interview with huntsman, herders and other people in the snow leopard population area.

Geoinformation technology and digital identification research methods have been used as powerful tools of sophisticated research on analyzing the population area of these animals, their prey-resources, migration mobility and other biological features. Geoinformation systems, remote sensing and geospatial data processing software applications allow to solve a wide range of research tasks that allow developing digital maps with areal of the snow leopard [6,7].

It should be noted that the degree of knowledge of any type of animal is an objective indicator of the difficulty of working with it in a natural environment. The problematic link in the study of large mammals is predators, which include the snow leopard itself. Their secretive lifestyle, the general sparseness of the population, and the inaccessibility of habitats minimize the possibility of their direct observations [8,9]. Well-adapted to the cold, dry conditions, snow leopards roam the high mountains up to altitude of $5000 \mathrm{~m}$ or more above sea level (a.s.l.), following the ibex and other wild ungulates from one river valley to another. Steep mountain slopes, rocky and rugged terrain provide ideal hunting grounds for these stealthy cats. The lifestyle of the Central Tien Shan snow leopard remains poorly understood due to the complexity of its geographical area, although according to some researchers it lives within its well defined territory $[10,11,12]$.

Snow leopards usually live alone, except for mothers and their cubs. Mating of snow leopards occur in February-March and the pregnancy of females lasts 98-103 days, she gives birth every 2 years to a litter of three or four cubs (very rarely up to 5), puberty occurs at the age of two. A female keeps cubs hidden for the first eight weeks and the cubs continue to live with their mothers for about two years [1,13].

Hunting the snow leopard in Kyrgyzstan has been prohibited since 1948, claims are established for hunting and trapping without a license since 1959. It is included in the International Red Book and attached to the Convention on International Trade in Endangered Species of WWF. Since 1975, it is included in the List of Specially Protected Species of Kyrgyzstan and is protected throughout the country [11].

Currently, in the framework of the Bishkek Declaration on the Conservation of the Snow Leopard adopted by the 12 snow leopard range countries in October 23, 2013, Bishkek, Kyrgyz Republic, a number of strategic international and national documents are developed. The current system of national legislation has been strengthened including increased penalties for illegal shooting of snow leopards to 1.5 million Kyrgyz Soms (more than 20 thousand USD) to protect this unique wild species.

Ongoing monitoring study has made it possible to assess the current state of the habitat of the snow leopard in the territory of the Khan Tengri State Nature Park (SNP) in the Central Tien Shan mountain region. The territory of the future Natural Park is one of the major habitats of the snow leopard in Kyrgyzstan. Camera traps have been used for detecting and identification of animals and collected photographs and geospatial datasets are processed and analyzed by applying open source Geoinformation software to contribute into conservation of this unique wild species. 


\section{Materials and methods}

\subsection{Study area}

The Khan Tengri State Natural Park is located in the eastern part of the Issyk-Kul region within the Sary-Zhaz river basin at junction of the Teskey Ala-Too and Kakshal-Too ridges of the Central Tien Shan (Fig. 1). Khan Tengri SNP is the largest nature park in Kyrgyzstan and the second largest in Central Asia. This region is characterized by the alternation of high mountain ranges and narrow valleys, the upper part of the valleys are moraine fields and glaciers that sources rivers. Its territory of 275800 hectares bordered by China and Kazakhstan $[9,14]$.
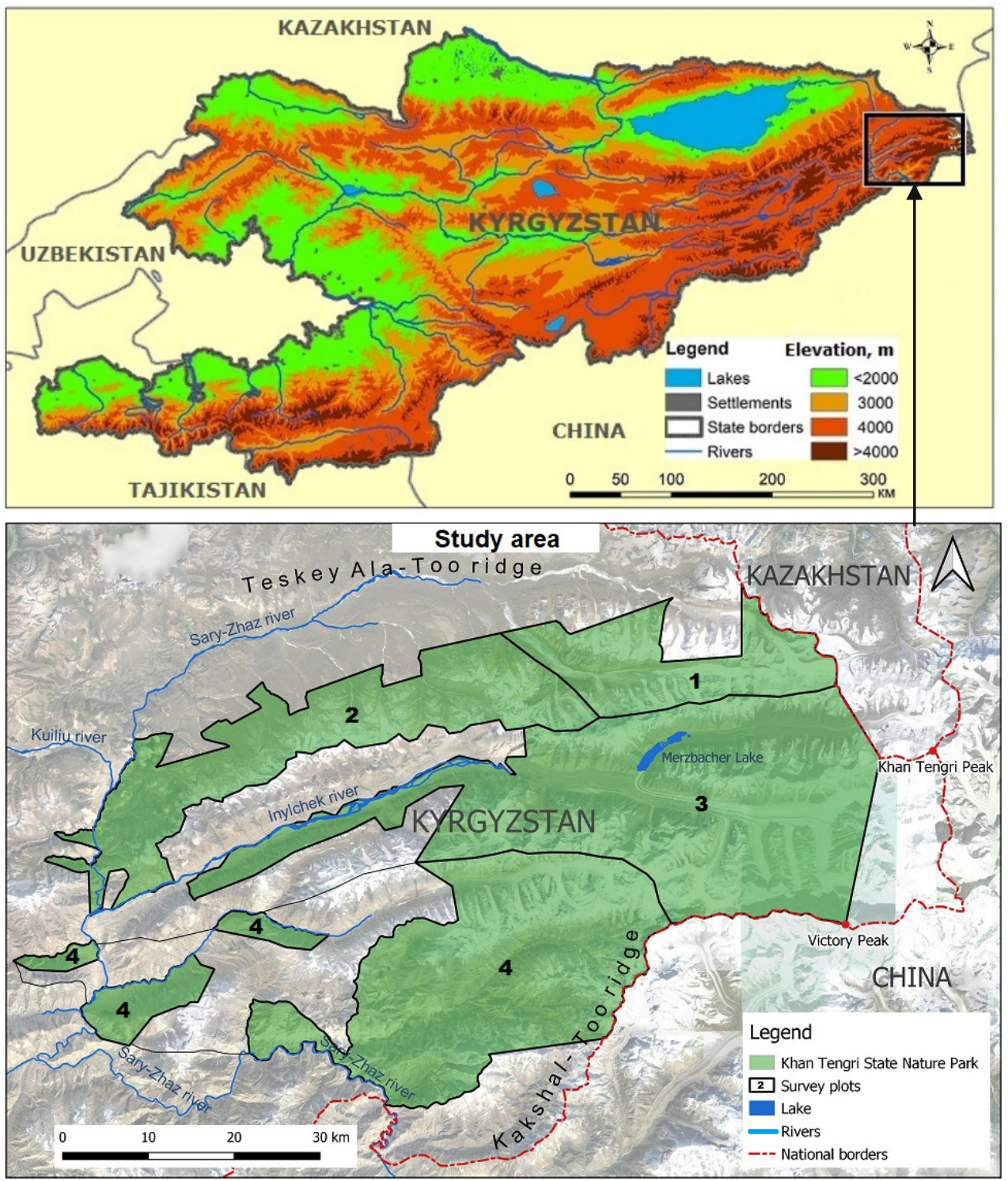

Fig. 1. Location of study area and survey plots: 1-Adyr-Tor; 2-Sary-Zhaz; 3-Inylchek; 4-Kaiyndy 
The Central Tien Shan region in geomorphological terms is characterized by great contrast, since it is represented by a massive uplift of this section by mountain ranges, rock outcrops and high peaks on the one hand, on the other hand it is heavily cut and dissected by river valleys, glacial troughs and cirques. Many of these glacial valleys with a huge amount of moraine deposits form unique mountain lakes of their kind, the most mysterious of which is Lake Merzbacher in the upper reaches of the Inylchek River Valley. There are the two highest points of the Tien Shan: Victory Peak 7439 m and Khan Tengri Peak 7010 $\mathrm{m}$. This mountain junction connects the largest mountain ridges of Kakshal-Too, Teskey Ala-Too and others $[15,16]$. Remoteness from the oceans, significant uplift and complex strongly rugged relief determined the continental climate of the region. Significant temperature fluctuations are characteristic both in the seasons of the year and during the day, low or moderate rainfall and relative dry air. Humidity increases, the duration of the frost-free period decreases. At altitudes of 3400-4000 m, frosts can be repeated throughout the entire warm season, and precipitation falls, as a rule, only in the form of snow. In the midlands, the air temperature in July is $10-15^{\circ}$ [17]. Winter in the mountains is longer and colder with air temperature in $-15-20^{\circ} \mathrm{C}$ in January reaching the absolute minimum $-45^{\circ} \mathrm{C}$.

\subsection{Materials}

To study the behavior, migrations and breeding of the snow leopard and other animals, camera traps were used (Fig. 2). 36 cameras have different operational modes that allow the user to customize its settings and tailor it to their specific needs (Table 1). They are used to detect and record the presence of rare species of wild animals in a particular area, to monitor their behavior, movement and abundance. The trapping-identification method using camera traps is one of the main tools at the moment for monitoring, determining the number of groups, and the migration routes of snow leopards $[18,19,20,21]$.

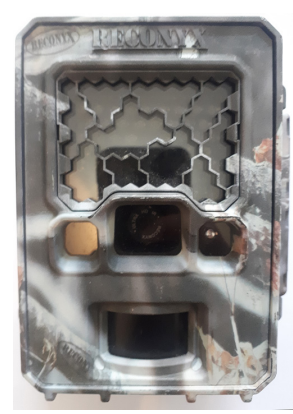

Fig. 2. Reconyx Hyperfire HC500 camera trap

Table 1. Camera trap specifications

\begin{tabular}{|l|l|l|c|}
\hline No. & \multicolumn{1}{|c|}{ Camera trap model } & \multicolumn{1}{|c|}{$\begin{array}{c}\text { Camera resolution, } \\
\text { trigger speed }\end{array}$} & $\begin{array}{c}\text { Quantity, } \\
\text { pieces }\end{array}$ \\
\hline 1 & Reconyx Hyperfire HC500 & $3.1 \mathrm{MP}, 0.29 \mathrm{sec}$ & 16 \\
\hline 2 & Trophy Cam HD Aggressor No-Glow Trail & $24 \mathrm{MP}, 0.2 \mathrm{sec}$ & 10 \\
\hline 3 & Cuddeback E3 Black Flash & $20 \mathrm{MP}, 0.25 \mathrm{sec}$ & 10 \\
\hline
\end{tabular}

Considering that the biological behavior of the snow leopard, which leads a very secretive and cautious way of life, and also that the territory of the study area is represented by high mountains, this method was chosen as the most suitable and efficient.

The grid cell method allows the effort to be spread out equally in the entire landscape and not get limited to known or easily accessible area used to cover in the study. A shape file with $5 \times 5 \mathrm{~km}$ grid cells has been created using QGIS to model transects for detecting paw prints, feces, wool, skeletons of dead animals by snow leopards and were superimposed on the study area. Such gridding enables to select particular sites that snow leopards were most likely to use in order to maximize detection rates of animals [6,22]. 
After preliminary planning of field work using detailed topographic and satellite maps of the area, three clusters were identified (Kaiyndy, Inylchek, Adyr-Tor) for installing camera traps. When choosing a camera trap installation, preference was given to areas where either traces of the leopard's vital activity (footprints, scraping, urine marks, excrement) were found, or at the paths intersections, next to a large stone, at the base of a cliff or at the narrowing of the path along the ridge (see Fig. 3). Camera traps should be mounted to trees or rocks with sensors located $50-90 \mathrm{~cm}$ above the path, while accounting for possible snow accumulations, and at a distance of 3.5-4 $\mathrm{m}$ from the animal's presumed trajectory, preferably perpendicular [20].
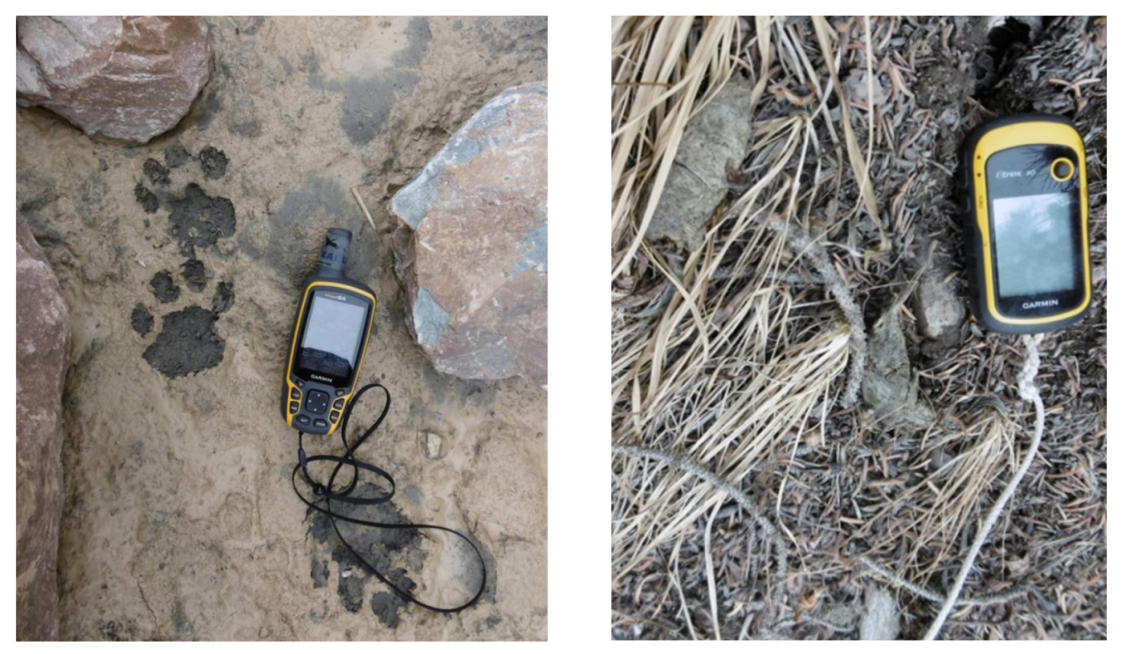

Fig. 3. Paw prints and excrements of a snow leopard

When installing camera traps, the following data was recorded in the field diary: installation date and time, GPS coordinates, installation height and camera number and memory card number. In the framework of this study, traps were installed between April 2018 and May 2019, approximately each camera trap at the installation point stood on average for five months, but the duration of the operation of individual traps may depend on the river flooding and other natural hazards.

After conducting field studies, the data from the camera traps is downloaded, processed and all indicators and locations of the camera locations are entered into GIS. Data is stored, processed and analyzed in GIS program, maps are created for each species of wild animals, and transects are loaded onto each individual map cells from the GPS navigator.

In total, from April 2018 to May 2019, camera traps were installed at 52 points in the Khan Tengri State Natural Park. On average, the period of activity of each camera trap in this area was 120 (max. 162 and min. 95) days. The average installation altitude of the camera traps was 3407 (max. 3915 and min. 2384) meters a.s.l.

In total, 15 different wildlife species (snow leopard, mountain goat, argali, bear (Ursus arctos), manul (Otocolobus manul), gray marmot (Marmota baibacina), fox (Vulpes vulpes), rabbit (Oryctolagus cuniculus), Himalayan snowcock (Tetraogallus himalayensis), ermine (Mustela erminea), weasel (Mustela nivalis), wolf (Canis lupus), badger (Meles meles), golden eagle (Aquila chrysaetos) and pika (Ochotona)) were recorded in the research area with camera traps. Some of these animal species are listed in the Red Book of Kyrgyz Republic. 


\subsection{Methods}

The next workflow is applied in the snow leopard monitoring investigations and mapping its distribution range, its food supply change and other unique species of animals in the territory of the Khan Tengri SNP (Fig. 4). The interviews with gamekeepers, hunters, herders and local people and field work were organized to identify the snow leopard living areal and their prey resources. The preliminary analysis of the snow leopard population area done and the monitoring sites with expected transects of animals for installation of the camera traps are identified.

Geoinformation technology is applied on collection, storage, processing, visualization and analysis of the research datasets on snow leopard monitoring. The open source Quantum GIS (QGIS) software is applied for geospatial data collection, processing and analysis in the research work.

To create and compose the mapping base of the research area using the QGIS program, cartographic shape file layers (Khan Tengri State Natural Park area, camera installation sites, hydrography, transportation, administrative borders etc.) were developed for spatial analysis and geodatabase development. Data collection, processing, visualization and analysis within the framework of QGIS allow designing and distribution of the digital and paper maps to use.

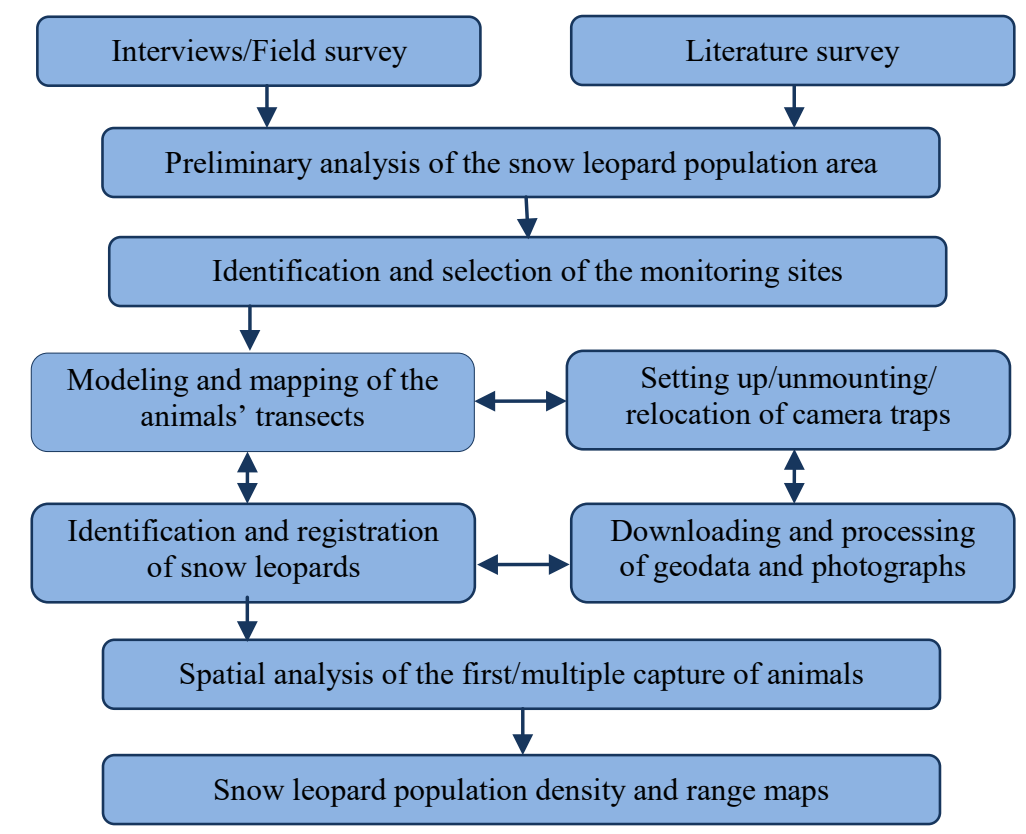

Fig. 4. Workflow of the snow leopard monitoring study

\section{Results}

The indicators from the traps with their coordinates are converted into a separate shape file layer with the $5 \times 5 \mathrm{~km}$ cells for further research with silhouette icons of the snow leopard superimposed. These silhouettes are created using a graphical editor using QGIS to compile a thematic map with points of fixation and presence in a given area (Fig. 5).

On the basis of the obtained images in the Khan Tengri State Natural Park, snow leopard individuals were identified using coat patterns of the animal's, which are unique for each snow leopard, as well as external distinguishing features of its body shape [23]. Most 
suitable for animal identification are body parts such as hind and forepaws, dorsal part of the tail, and also a pattern of dark spots throughout the body of the snow leopard (Fig. 6).

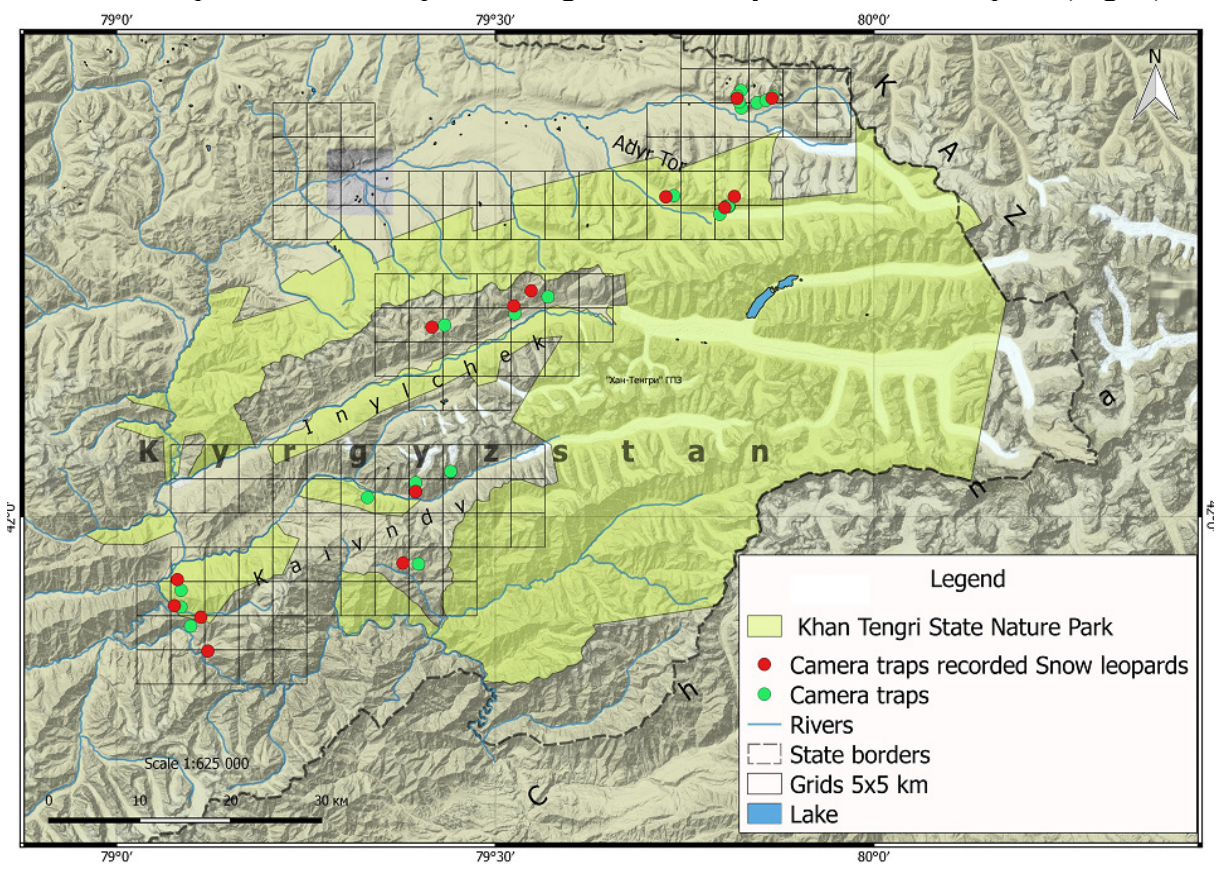

Fig. 5. Living areal of snow leopard fixed by camera traps
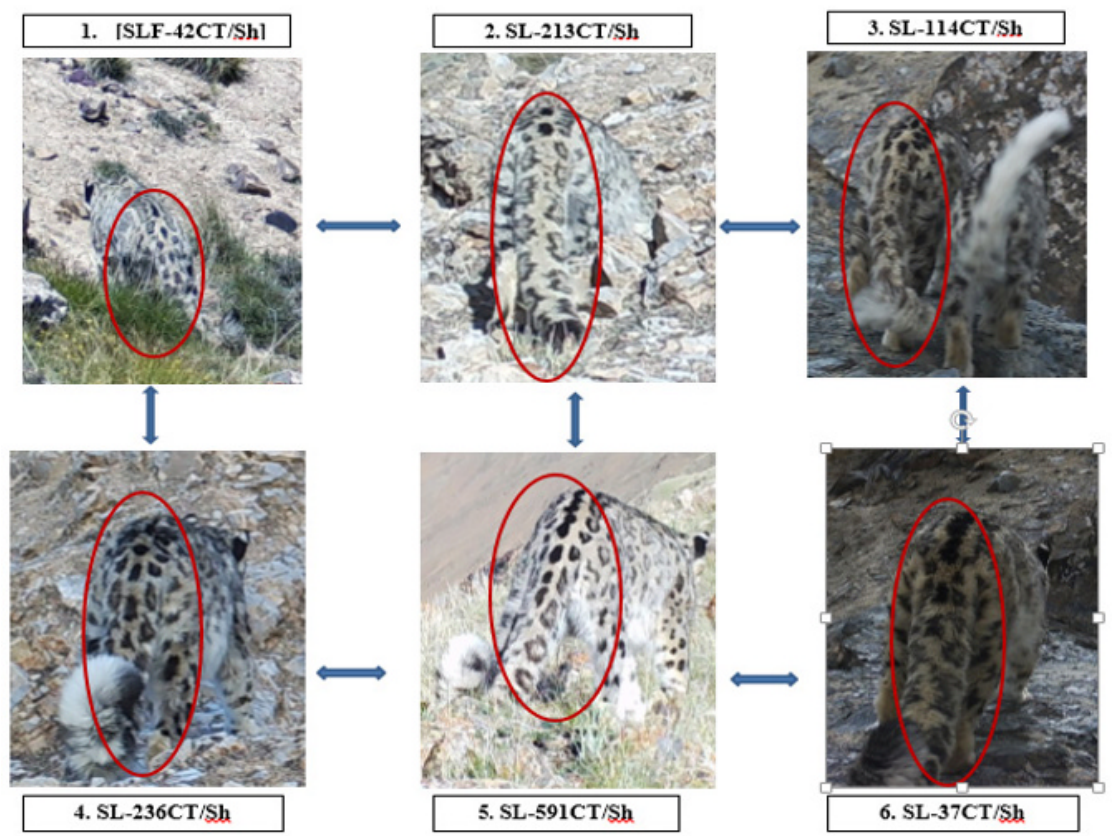

Fig. 6. Identification of six different snow leopards based on their tail patterns

As a result of photo-identification, a special passport is created for a certain type of animals, in which data on a specific individual snow leopard are recorded during the following camera traps. Snow leopard passport is compiled on the basis of images suitable 
for identification by their body patterns. After this procedure the individual snow leopard has been identified and an individual identification code (IIC) is assigned to it (Table 2).

In most images, it is not immediately possible to identify gender, since sexual dimorphism in snow leopards is not clearly expressed, the exception is family groups consisting of one female with kittens.

Thus, there are 16 adults and 9 snow leopard cubs identified in the Kaiyndy, Inylchek and Adyr-Tor sites in the territory of the Khan Tengri State Natural Park in the Central Tien Shan according to the results of the study conducted in 2018-2019 (Fig. 7).

Table 2. Special passport of the snow leopard

\begin{tabular}{|c|c|c|c|c|c|}
\hline ID code & $\begin{array}{l}\text { Date/ } \\
\text { Time }\end{array}$ & Location & $\begin{array}{c}\text { GPS/WGS-84 } \\
\text { Coordinates }\end{array}$ & $\begin{array}{c}\text { Altitude, } \\
\text { m a.s.l. }\end{array}$ & $\begin{array}{c}\text { Photography of the snow } \\
\text { leopard }\end{array}$ \\
\hline $\begin{array}{c}{[\mathrm{SL}-} \\
416 \mathrm{CT} / \mathrm{Sh}]\end{array}$ & $\begin{array}{l}03.10 \\
2018 \\
10: 04\end{array}$ & $\begin{array}{c}\text { Central } \\
\text { Tian } \\
\text { Shan, } \\
\text { Inylchek } \\
\text { valley }\end{array}$ & $\begin{array}{l}42.18467 \mathrm{~N} \\
79.41640 \mathrm{E}\end{array}$ & 3780 & 8 \\
\hline
\end{tabular}

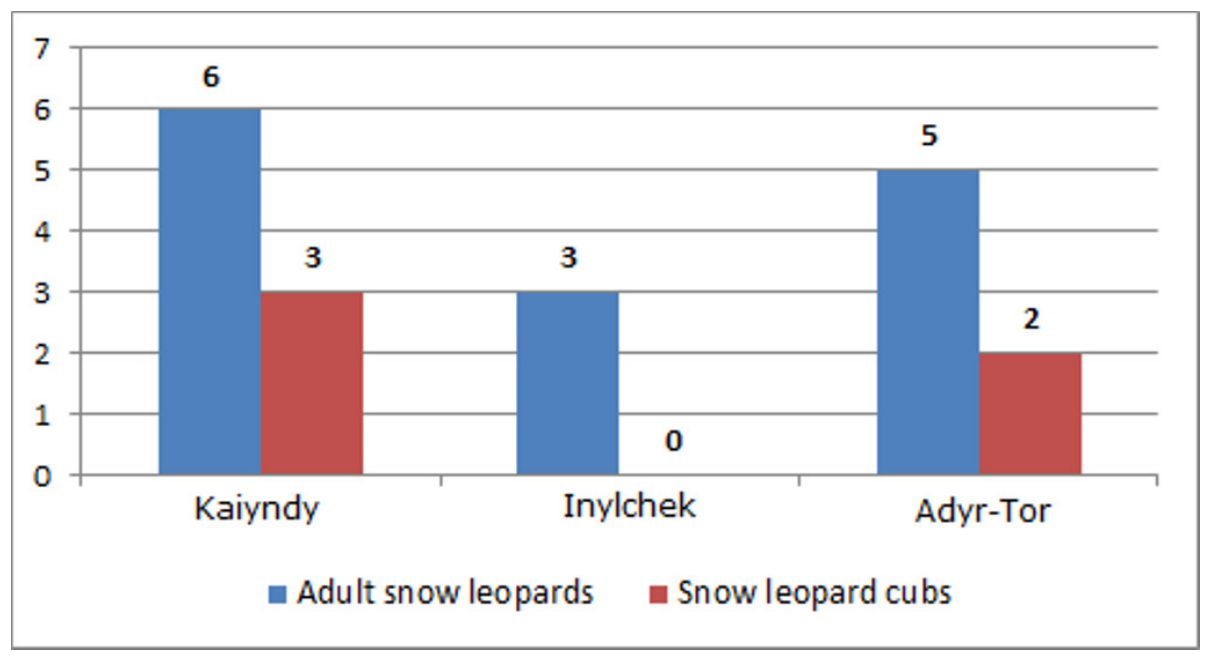

Fig. 7. Number of registered snow leopards in the survey plots

\section{Conclusion}

Based on the first study using new monitoring methods in the territory of the Khan Tengri State Natural Park, the approximate abundance of the snow leopard and its distribution area have been preliminarily analyzed. It should be noted that this region is unique for its species diversity, natural landscapes in many cases are not subject to active anthropogenic impact. The creation of the State Natural Park in 2016 is dedicated to the conservation of pristine nature and representatives of fauna and flora.

But meanwhile, there are problems in particular, the region began to be actively used as year-round pastures for the cultivation of yaks, cattle and small cattle. Which in turn 
violates the food base of the snow leopard in some cases, geological exploration is underway in some areas, which in the future can also negatively affect these landscapes. There are also hunting grounds in the border territory of the Khan Tengri SNP (buffer zone), in some cases such hunting facilities are located inside the park itself, where the general silence of natural ecosystems is violated, etc.

In total 19 snow leopards are registered with camera traps and they are living in the Kaiyndy, Inylchek and Adyr-Tor sites of the Khan Tengri State Natural Park. Each of the designed $5 \times 5 \mathrm{~km}$ grid cells have installed cameras and recorded animals and birds in their areal. 14 adult and 5 snow leopard cubs are detected and positioned in the digital map of study area with their further identification and registration. Whole area of the park will be investigated in the next research activities to record and monitor existing snow leopard's population.

The environmental conditions of the natural park as a whole are favorable for reproduction of animals, which creates the prerequisites for the reproductive core, and with the successful protection of high mountain ecosystems, even to increase its number in the indicated region. Use of Geoinformation systems and camera traps allows to continue research activities on detecting, identification and mapping of the snow leopards in the all territory of the Khan Tengri SNP as well as in the other wildlife reservation areas of the country.

This work was supported by the German Nature and Biodiversity Conservation Union (NABU) in Kyrgyzstan.

\section{References}

1. E. P. Koshkarev. Snow leopards in Kirgizia (areal structure, ecology, protection) [Снежный барс в Киргизии: Структура ареала, экология, охрана]. Frunze, Ilim, p.100 (in Russian) (1989)

2. E. P. Koshkarev, V. Vyrypaev. The snow leopard after the break-up of the Soviet Union [Что случилось со снежным барсом после распада CCCP?]. Cat News, 32, P.9-11 (in Russian) (2000)

3. A. Alamanov, F. Balbakova, O. Lipka. Climate change vulnerability assessment for Central Tian-Shan, Kyrgyzstan. Technical Report. DOI: 10.13140/RG.2.1.1696.5523 (2015)

4. V. I. Toropova, V.G. Radchenko, A. Rasakhun kyzy, S. Sagymbaev. Results of monitoring of snow leopard over a five year period (Kirgiz, Terskei and Kungei AlaToo ranges) [Результаты монторинга снежного барса за пятилетний период (Кыргызский Терскей и Кунгей Ала-Тоo]. Issledovaniya bioraznoobraziya na BT “Issyk-Kul” 3: P.85-86 (in Russian) (2005)

5. M. Sulaimanova. There are 330 snow leopards in Kyrgyzstan [В Кыргызстане имеется 330 снежных барсов]. Bishkek, Kabar News. Retrieved from https://www.meteoblue.com/en/weather/historyclimate/climatemodelled/inylchekglacier_kyrgyzstan_1526997 (2020)

6. V. Tytar, A. DeKastle, M. Hammer. Mountain ghosts: protecting snow leopards and other animals of the Tien Shan mountains of Kyrgyzstan. Expedition Report, NABU. p. 88 (2016)

7. T. Mahmood, A. Younas, F. Akrim, S. Andleeb, A. Hamid, M.S. Nadeem. Range contraction of snow leopard (Panthera uncia). PLOS ONE 14(8): e0218460. https://doi.org/10.1371/journal.pone.0218460 (2019) 
8. M. Y. Paltsyn, S.V. Spitsyn, A.N. Kuksin, S.V. Istomov. Snow leopard conservation in Russia. Krasnoyarsk: Gorod Publishing House. p.99 (2012)

9. G. A. Lazkov, A.T. Davletbakov, D.A. Milko, M.R. Ganybaeva. Atlas of flora and fauna of the protected areas in Central Tien Shan (Kyrgyz Republic) [Атлас флоры u фауны особо охраняемых природных территорий Центрального Тянь-Шаня (Кыргызская Республика)]. - Bishkek, P. 298-320 (in Russian) (2016)

10. E. A. Kreuzberg-Mukhina, A.V. Esipov, E.A. Bykova, E.V. Vashetko, B. Aromov. Development of the National Action Plan for the conservation of Snow Leopard in Uzbekistan. Final Report on the ISLT project. Tashkent, Uzbek Zoological Society and State Committee of Nature Protection (2003)

11. Red Book of the Kyrgyz Republic [Красная книга Кыргызской Республики]. State agency on environment protection and forestry under the Government of Kyrgyz Republic. Institute for Biology and Pedology of National Academy of Sciences of Kyrgyz Republic. Ecological Movement "Aleine" of Kyrgyzstan. - 2 ed. - Bishkek. p. 544 (in Russian) (2006)

12. F. Balbakova, A. Alamanov, O. Lipka, O. Pereladova. Climate Change Vulnerability Assessment in Snow Leopard Habitat Central Tian Shan Region of the Kyrgyz Republic. WWF Project Report (2017)

13. V. I. Toropova, T. Harder. Protection of the snow leopard in the Central Asian countries. Ecological Herald "Murok", Bishkek, No.1 (2002)

14. D. Mallon, M. Kulikov. Aspects of trans-boundary snow leopard conservation in Central Asia. Report of the FFI/CMS workshop, Bishkek, Kyrgyzstan (2014)

15. S. K. Alamanov, K.S. Sakiev et al. Physical Geography of Kyrgyzstana [Физическая география Кыргызстана] (Collective monograph: 589 pp.). Turar. Bishkek. P.140141 (in Russian) (2013)

16. Atlas of the Kyrgyz Republic [Атлас Кыргызской Республики]. Moscow: Head Office of Geodesy and Cartography. p.157 (in Russian) (1987)

17. Meteoblue. Climate Inylchek Glacier. Retrieved from https://www.meteoblue.com/en/weather/historyclimate/climatemodelled/inylchekglacier_kyrgyzstan_1526997 (2020)

18. R. M. Jackson, J.D. Roe, R. Wangchuk, D.O. Hunter. Surveying Snow leopard Population with Emphasis on Camera Trapping: A Handbook. The Snow Leopard Conservancy. Sonoma, California (2005)

19. M. Ancrenaz, A. Hearn, J. Ross, R. Sollmann, A. Wilting. Handbook for wildlife monitoring using camera traps. BBEC II Secretariat (2012)

20. A. S. Karnaukhov, M.P. Korablev, A.N. Kuksin, S.V. Malykh, A.D. Poyarkov, S.V. Spitsyn, M.D. Chistopolova, J.A. Hernandez-Blanco. Snow Leopard Population Monitoring Guidebook. - WWF. Krasnoyarsk. p.164 (2020)

21. A. A. Grachev, Yu.A. Grachev, S.K. Saparbaev, A.D. Djanyspaev. Manual for monitoring snow leopards in Kazakhstan [Методическое руководство-пособие по мониторингу снежного барса в Казахстане]. Astana. p.32 (in Russian) (2016)

22. J. S. Alexander, A.M. Gopalaswamy, K. Shi, J. Hughes, P. Riordan. Patterns of Snow Leopard Site Use in an Increasingly Human-Dominated Landscape. PLOS ONE 11(5): e0155309. https://doi.org/10.1371/journal.pone.0155309 (2016)

23. R. M. Jackson, J.D. Roe, R. Wangchuk, D.O. Hunter. Estimating Snow Leopard Population Abundance Using Photography and Capture-Recapture Techniques. Wildlife Society Bulletin. 34. P.772-781. 10.2193/0091-7648 (2006) 